[CONTRIBUTION FROM THE CHEMICAL LABORATORY OF THE UNIVERSTTY OF MICHIGAN.]

\title{
NOTES ON SUGAR BEETS.
}

BY P. F. TROWBRIDGE.

Received lanuary 8 , 1905 .

OBTAINING THE TARE.

\begin{abstract}
$\Lambda \mathrm{T}$ the different beet-sugar factories in Michigan, two methods $A$ are used for finding the amount of tare (dirt adhering to the beets).
\end{abstract}

I. A half bushel of beets is taken from each wagon or car, as a sample, satisfactory to both the farmer and the factory representative. From this sample 20 or 25 pounds are carefully weighed. These beets are then well brushed with bristle brushes, and retopped if the whole of the crown has not been removed. The beets are again weighed and the loss in weight computed to per cent. is reported as the amount of tare.

2. The weighed sample is washed in a revolving washer, allowed to drain for a few minutes, retopped if necessary and again weighed. The loss in weight is reported in terms per cent. The second method requires less labor and is more rapid. It is also more nearly in accord with the factory operation. The first method fails to remove every particle of dirt, but does remove many small rootlets and a small amount of the outside of the beets, especially if they have been frozen.

In method 2, the adherent water tends to decrease the amount of tare. In the following series of experiments made at one of the Michigan factories, care was exercised to make both samples from each load as representative as possible.

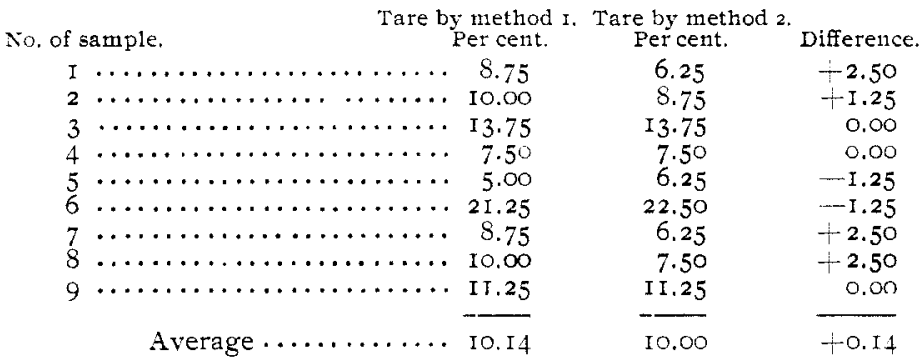

A further advantage of the second method is that frozen beets may be tared at once tusing warm water in the washer. 
ANALYSIS OF THE SAMPLE.

The percentage of sugar in the beet is determined, in all the Michigan factories, by the indirect method of juice analysis, using a factor to express the results in terms of per cent. in the beets. A brief resumé of the methods employed may be of interest.

A portion of the tared sample (usually longitudinal quarters of six or eight beets) is pulped in a revolving grater. The pulped sample is mixed, pressed in a lever press, and the juice sent to the chemist for analysis. Factory methods vary somewhat at this point: (I) The sample is allowed to stand for fifteen or twenty minutes to allow the air bubbles to escape, after which the Brix reading is taken with correction for temperature; then roo cc. of the sample are poured in to a double graduated flask ( IOO-I Io cc.), and ro cc. of basic lead acetate solution added. If foam renders filling to the mark difficult, a drop of ether or alcohol is used. The sample is thoroughly mixed, filtered through a dry filter and polarized. The per cent. of sugar in the juice is given in Schmitz's tables, and the factor adopted by the factory is used to express the results in terms of per cent. sugar in the beet. (2) After the Brix reading a double normal sample (52. I grams) is measured with a sucrose pipette, which has a graduation on the stem indicating the amount to be taken for the different degrees Brix. The pipettes have been graduated with a pure sugar solution, and are not strictly accurate for beet juices, but the error is well within the range allowed by commercial methods. The sample is transferred to a graduated flask, Ioo or $200 \mathrm{cc}$, 6 or $8 \mathrm{cc}$. of lead acetate solution added, the flask filled to the mark, and the sample mixed, filtered, and polarized. If $100 \mathrm{cc}$. flasks are used, one-half the reading gives the per cent. sugar in juice, and the factor gives per cent. in beet. (3) A double normal sample of the juice is weighed on a balance sensitive to ro $\mathrm{mg}$; 住 All the methods give results, the commercial accuracy of which cannot be questioned. Method (I) by employing a larger sample reduces the errors of manipulation and reading, and is thus preferred by the writer.

THE FACTOR TO SHOW THE REIATION BETWEEN SUGAR IN JUICE TO SUGAR IN BEET.

The true factor to represent the relation of sugar in juice to 
sugar in beet has been the subject of some controversy and hard feeling between the farmers and the factory managers. During the campaign of a year ago some of the Michigan factories used the factor 0.95 , others as low a factor as 0.90 , and it was claimed that one factory used a factor of 0.87 . The factor 0.95 was formerly employed by the German chemists and was based on the fact that the marc in the beet is usually not far from 5 per cent. Scheibler's method of direct beet analysis showed the error of this assumption, and has brought about the abandonment of this factor on the continent. ${ }^{1}$ During the fall and winter of 1899 the writer made a series of twenty-five analyses (method of operation given below) to determine this factor and found as an average 0.919 , with a maximum of 0.956 , and a minimum of 0.875 . The table of results as given below is arranged not in order of the analyses but in order of the value of the factor.

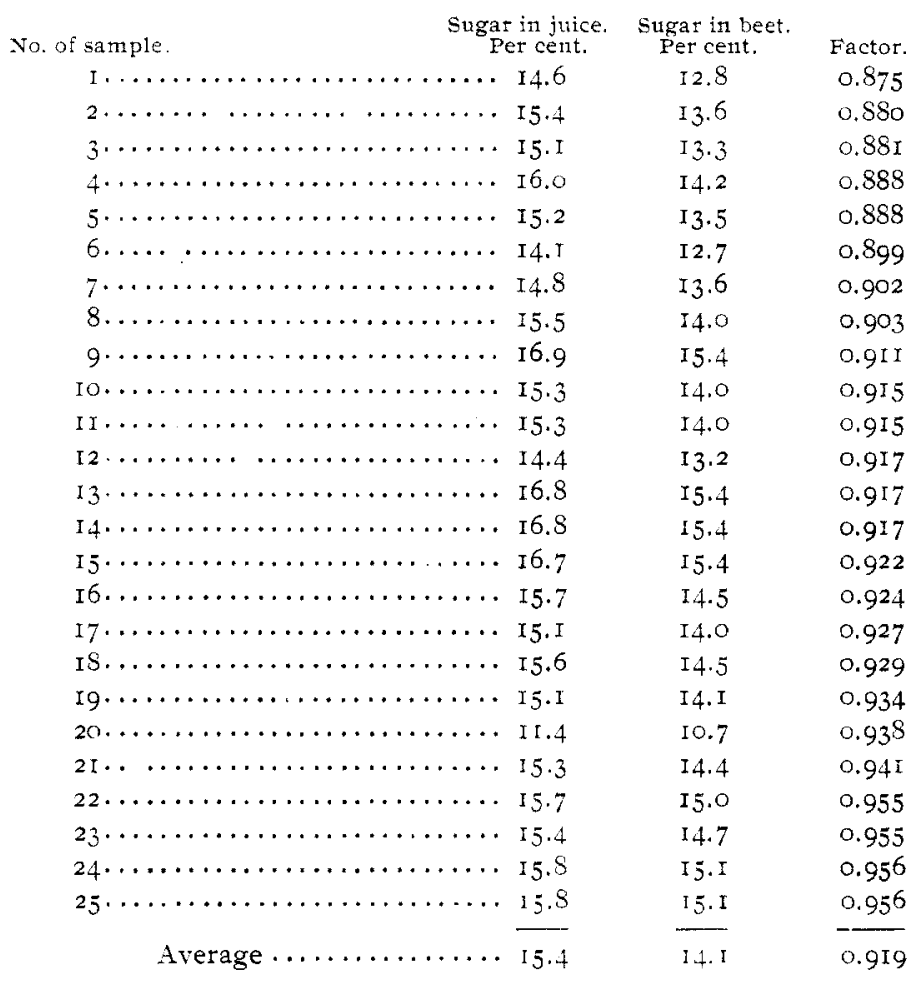

1 Stohmann: "Zucker Fabrikation," (1900), 4te Aufl., p. 52. 
METHOD OF ANALYSIS IN DETERMINING FACTOR.

The finely pulped samples are well mixed and duplicate samples are weighed for determination of sugar in beet by the hot alcohol digestion method. The remainder of the pulp is pressed in a lever press, and the juice analyzed by the methods previously described. The samples of pulp, 52. I grams, are transferred to a $20 \mathrm{I} .2 \mathrm{cc}$. flask, 6 to $8 \mathrm{cc}$. of basic lead acetate solution are added, and the flask is then filled three-fourths full of 90 per cent. alcohol. After the flask is fitted with a condenser tube it is heated, immersed in a water-bath, for thirty minutes. Care must be taken that the alcohol does not boil so violently as to force the pulp and juice into the condenser tube. The condenser tube and the neck of the flask are then rinsed with alcohol, and the flask filled nearly to the mark, the flask being turned from side to side to insure the removal of all air bubbles. The flask is then returned to the water-bath for three or four minutes, or until the alcohol is heated nearly to boiling. The contents of the flask are then cooled to about $17.5^{\circ}$. The flask is filled to the mark, thoroughly shaken, and the contents filtered through a dry filter, and polarized. In the filtering, the funnel must be covered to prevent evaporation of the alcohol, and the temperature of the room must be as nearly $17.5^{\circ}$ as possible. ${ }^{1}$ The reading of the polariscope gives the per cent. of sugar in the beet direct. The sugar in the juice divided by the sugar in the beet gives the factor.

During the campaign of a year ago, shortly after the writer had made the analyses reported above, Mr. E. E. Ewell, first assistant chemist of the Department of Agriculture, was called into the state to examine the working of one of the beet-sugar factories, and made eight analyses to determine the factor. He reported ${ }^{2}$ an average factor of 0.9275 , maximum 0.945 , minimum 0.902 .

During the present campaign the Holland Sugar Co., of Holland, Michigan, saves a handful of pulp from every sample analyzed, and for every ten samples this pulp is mixed and analyzed by hot water digestion. This establishes a factor for every ten samples. During three weeks in October they reported to the writer the finding of average factors of $0.91,0.913$, and 0.912 .

The writer has made a number of analyses of beets grown the past season in a further study of this problem, with the following

1 See Wiley: This Journal, 21, 568 (1899).

2 House Document, No.699, p. 146 . 
results: Average factor 0.917 , minimum 0.883 , maximum 0.955 .

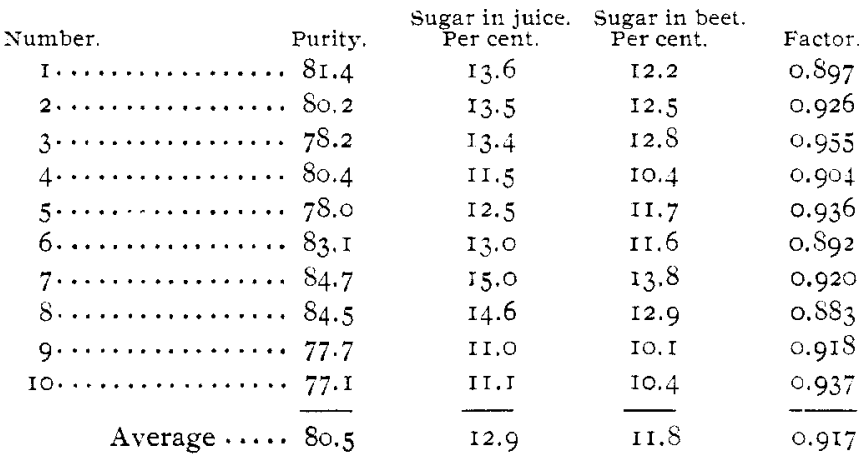

Mr. Ewell, ${ }^{1}$ in his report, calls attention to reasons why there should be so great variations in the relation existing between the sugar in the juice and that in the beet as a whole. It is quite erident that the average factor expressing this relation lies between 0.91 and 0.92 . If any one grower of beets has a large number of loads to deliver and thus obtains the average of many analyses the use of an average factor will not work injustice to either party. On the other hand the average of a few samples only, may work an injustice to the grower or to the factory.

Owing to the great number of analyses made daily at the factories ( 100 to 300 ), the chemists are forced to use the indirect method of juice analysis. The hot alcohol digestion method is too slow and also too expensive. The hot water digestion method, although more rapid than the hot alcohol digestion, is yet too slow for factory use under present factory conveniences. The instantaneous diffusion method of Pellet ${ }^{2}$ can be made rapid enough for factory work, but so far as I am aware, it has not yet superseded the indirect method in any of the sugar factories in this country. Difficulty is experienced in pulping the beets sufficiently fine to insure accuracy of results. Theoretically every cell wall should be broken. The sugar does not diffuse through the cell walls with cold water until after the cell walls have been heated.

THE MARC AND THE FACTOR,

It has been shown that the old factor 0.95 , based on the approximate 5 per cent. of marc, has no justification. A few actual

1. Lor. rit.

2 Spencer: "Handbook for Beet-Sugat Chemists," p. 1s: (369g).

3 Stohman : Loc, cit., p. Iro. 
determinations of marc and factor in the same sample will be of interest. The marc (insoluble fiber) determinations were made as directed by Fruehling and Schulz. ${ }^{1}$

\begin{tabular}{|c|c|c|c|c|c|}
\hline Numbe & $\begin{array}{c}\text { Marc. } \\
\text { Per cent. }\end{array}$ & $\begin{array}{c}\text { Sugar in juice. } \\
\text { Per cent. }\end{array}$ & $\begin{array}{l}\text { Sugar in beet. } \\
\text { Per cent. }\end{array}$ & Fac & $\begin{array}{l}\text { Factor on } \\
\text { basis of marc. }\end{array}$ \\
\hline I. & $\ldots \ldots \ldots \ldots \ldots 4.47$ & 13.58 & 12.17 & 0.896 & 0.9553 \\
\hline 2. & $\ldots \ldots \ldots \ldots \ldots 4.53$ & 13.48 & 12.53 & 0.930 & 0.9547 \\
\hline $3 \cdot$ & $\ldots \ldots \ldots \ldots \ldots 4.14$ & II. 43 & 10.66 & 0.933 & 0.9586 \\
\hline $4^{2}$ & $\ldots \ldots \ldots \ldots \ldots 5.20$ & 14.4 & II.3 & 0.785 & 0.9480 \\
\hline $5^{3}$. & $\ldots \ldots \ldots \ldots \ldots 4.42$ & I 4.2 & I0.3 & 0.725 & 0.9558 \\
\hline
\end{tabular}

VARIATIONS OF SUGAR CONTENT IN BEETS GROWN UNDER APPARENTLY UNIFORM CONDITIONS.

Complaint has been made at different factories in the state that two loads of beets drawn from the same field, and often from the same pit, would vary several per cent. in sugar content. At Marine City this year an average sugar content for about 60 acres of beets for one man was 44 per cent., yet from the same field one load gave II.8 per cent. and another 18 per cent. This variation is in part due to the variable factor as discussed in the section above, and aiso in the variation in the sugar content in beets grown under apparently uniform conditions.

The writer raised a small patch of beets last season, about 25 by 50 feet, planting them in rows 16 inches apart, and thinning to about 9 inches in the row. From the patch $\mathrm{I} 20$ beets were selected that were of good form and size. Each of these beets were analyzed separately for sugar content some six weeks after they had been pulled. The average sugar content was $12.6 \mathrm{I}$ per cent ; the lowest was 8.7 per cent., and the highest 18.2 per cent.

Of these 120 beets:

\begin{tabular}{|c|c|c|c|c|c|c|c|}
\hline \multicolumn{3}{|c|}{ I beet contained between } & \multicolumn{2}{|c|}{8 and } & \multicolumn{3}{|c|}{9 per cent. sugar (8.7). } \\
\hline I & “ & " & 9 & " & IO & " & $"$ \\
\hline$\because$ & $\because 6$ & “" & 10 & $\because$ & II & " & ، \\
\hline$\because$ & " & " & II & $"$ & 12 & " & ، \\
\hline ऑ & " & “ & 12 & " & I3 & ، & “ \\
\hline « & $"$ & “ & I3 & " & I4 & “ & ، \\
\hline 8 ' & " & “ & 14 & " & I5 & ، & “ \\
\hline $4 ،$ & "، & " & 15 & " & J6 & " & “ \\
\hline I $" 6$ & “ & " & 16 & "6 & 17 & “ & “ \\
\hline $0 " ،$ & “ & “ & 17 & “ & I 8 & ، & “ \\
\hline ، & ، & " & 18 & $"$ & 19 & " & $(18.2)$. \\
\hline
\end{tabular}

1 "Anleitung," 5 th edition, p. I85.

2 Sample No. 4 consisted of a very large hollow beet, but not decayed.

${ }^{3}$ Sample No. 5 consisted of three green beets. 
It is surprising that beets grown under apparently uniform conditions of soil and culture should show such a range of sugar con. tent. The variation of sugar content in individual beets shows the necessity of taking similar portions of several beets for the sample rather than the whole of one or two beets.

The purity (percentage of sugar in total solids) in ten samples from the same patch of beets averaged 80.5 per cent. and ranged from 77.1 to 84.7 , as shown in the table on page 220 .

COMPARISON OF ANALYSES BY DIGESTION WITH HOT ALCOHOL. AND HOT WATER.

The German chemists have adopted the digestion with hot alcohol as the standard, while the French chemists rely upon the digestion with hot water. It will be of interest to compare the restilts of the two methods. The samples of beets were all grated on a hand vegetable grater, thoroughly mixed, and double normal samples weighed for analysis. The time of digestion was onehalf hour in all cases. The general plan of manipulation as given in Fruehling and Schulz was followed. Duplicate samples were taken in every case, three readings being made for each sample. The per cent. reported in the following table is the average of the six readings.

\begin{tabular}{|c|c|c|c|}
\hline No. of sample. & $\begin{array}{l}\text { ohol digestion. } \\
\text { er cent. sugar. }\end{array}$ & $\begin{array}{l}\text { Water digestion. } \\
\text { Per cent. sugat. }\end{array}$ & $\begin{array}{l}\text { Difference. } \\
\text { Per cent. }\end{array}$ \\
\hline I $\ldots \ldots \ldots \ldots \ldots \ldots \ldots \ldots$ & .12 .50 & 12.30 & -0.2 \\
\hline $2 \ldots \ldots \ldots \ldots \ldots \ldots \cdots \cdots$ & . 12.65 & 12.59 & -0.06 \\
\hline $3 \ldots \ldots \ldots \ldots \ldots \ldots \ldots$ & .. 13.30 & 13.20 & -0.1 \\
\hline $4 \ldots \ldots \ldots \ldots \ldots \ldots \ldots$ & . Ir.9o & $1 \mathrm{I} .73$ & -0.17 \\
\hline $5 \ldots \ldots \ldots \ldots \ldots \ldots \ldots$ & . 15.48 & 15.28 & -0.20 \\
\hline $6 \ldots \ldots \ldots \ldots \ldots \ldots \ldots$ & .. 16.00 & 15.79 & $-0.2 \mathrm{I}$ \\
\hline $7 \ldots \ldots \ldots \ldots \ldots \ldots \ldots$ & 15.06 & I4.66 & -0.4 \\
\hline $8 \ldots \ldots \ldots \ldots \ldots \ldots \ldots$ & .. Ix,8I & II. $8 \mathrm{I}$ & 0.00 \\
\hline $9 \ldots \ldots \ldots \ldots \ldots \ldots$, & $=13.23$ & 13.44 & +0.21 \\
\hline $10, \ldots \ldots \ldots \ldots \ldots \ldots \ldots$ & .12 .70 & 13.05 & +0.35 \\
\hline r $\ldots \ldots \ldots \ldots \ldots \ldots \ldots$ & - 13.10 & 13.02 & -0.08 \\
\hline I $2 \ldots \ldots \ldots \ldots \ldots \ldots \ldots$ & $\therefore \quad 12.29$ & 12.72 & +0.43 \\
\hline $1_{3} \ldots \ldots \ldots \ldots \ldots \ldots \ldots$ & .. 13.54 & 13.24 & -0.3 \\
\hline$r_{4} \ldots \ldots \ldots \ldots \ldots \ldots \ldots$ & . $I_{3} .20$ & 13.11 & -0.09 \\
\hline${ }_{15} \ldots \ldots \ldots \ldots \ldots \ldots$ & . II 86 & 12.19 & $\div 0.33$ \\
\hline $16 \ldots \ldots \ldots \ldots \ldots \ldots \ldots$ & . 12.63 & 12.96 & +0.33 \\
\hline 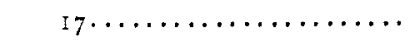 & . 13.88 & 13.64 & -0.28 \\
\hline $18 \ldots \ldots \ldots \ldots \ldots \ldots \ldots \ldots$ & . 13.98 & $\mathrm{I} 3.9^{8}$ & 0.00 \\
\hline Ig $\ldots \ldots \ldots \ldots \ldots \ldots \ldots \ldots, \ldots$ & . 16.68 & 16.53 & -0.15 \\
\hline ......... & $\mathrm{I} 3.4 \mathrm{I}$ & 13.43 & -0.02 \\
\hline
\end{tabular}


The average of error between the two methods is scarcely greater in any case than would be likely to occur in ordinary duplicate analyses. Certainly the above results do not indicate that 0.2 per cent. should be deducted from all hot water digestions to give the correct data, as was maintained to the writer last winter by a German sugar chemist.

THE RICHEST PORTION OF THE BEET.

In answer to many inquiries some analyses were made tending to show what portion of the beet has the greatest sugar content. The samples were all carefully topped at the leaf line, thoroughly brushed and divided horizontally into approximately three equal portions. The samples were grated by hand, carefully mixed and analyzed by the hot water digestion method. The results are given in the following table:

\begin{tabular}{|c|c|c|c|}
\hline No. of sample. & $\begin{array}{l}\text { pper portion } \\
\text { of beet. } \\
\text { cent. sugar. }\end{array}$ & $\begin{array}{l}\text { Middle portion } \\
\text { of beet. } \\
\text { Per cent. sugar. }\end{array}$ & $\begin{array}{l}\text { Lower portion. } \\
\text { of beet. } \\
\text { Per cent. sugar. }\end{array}$ \\
\hline I $\ldots \ldots \ldots \ldots \ldots \ldots$ & . IT.2O & $\mathrm{I} 3.20$ & 13.50 \\
\hline $2 \ldots \ldots \ldots \ldots \ldots \ldots$ & .. II.60 & 12.30 & II. 60 \\
\hline $3 \ldots \ldots \ldots \ldots \ldots \ldots$ & . $\quad 9.93$ & 9.98 & 9.73 \\
\hline $4 \ldots \ldots \ldots \ldots \ldots \ldots$ & .. II.I6 & 13.64 & 12.87 \\
\hline $5 \ldots \ldots \ldots \ldots \ldots \ldots \ldots$ & .. 11.70 & I3.90 & 10.80 \\
\hline $6 \ldots \ldots \ldots \ldots \ldots \ldots$ & .. 10.10 & I I. 30 & 10.30 \\
\hline $7 \ldots \ldots \ldots \ldots \ldots \ldots$ & .. II.60 & I2. IO & 14.20 \\
\hline $8 \ldots \ldots \ldots \ldots \ldots$ & . 9.10 & I0.40 & II. 10 \\
\hline $9 \ldots \ldots \ldots \ldots \ldots \ldots$ & . IO. 50 & 12.40 & IO. IO \\
\hline 1o $\ldots \ldots \ldots \ldots \ldots \ldots \ldots$ & .. I I. 08 & I 3.2 & 13.00 \\
\hline Average.....$\ldots$. & .. 10.9 & I 2.2 & II.7 \\
\hline
\end{tabular}

Where only portions of beets are used to make up the sample for analysis, a full-length longitudinal section should be taken, and the same fractional portion of each beet.

[CONTRIBUTIONS FROM THE SHEFFIELD LABORATORY OF YAIE UNIVERSITY.]

ON THIOUREAAMIDINES : A CORRECTION.

By HENRY I. WHFELER.

Received February 9, 190r.

REENTLY Wheeler and Sanders ${ }^{1}$ published an article on ureaimido esters, thioureaimido esters, acylthioureaimido esters and ureaamidines. An examination of the behavior of the ureaimido esters towards organic bases showed that they reacted

1. This Journal, 22, 365 . 